\title{
New mechanisms driving muscle stem cell regenerative decline with aging
}

\author{
PEDRO SOUSA-VICTOR ${ }^{1}$, LAURA GARCÍA-PRAT ${ }^{2,4}$, PURA MUÑOZ-CÁNOVES ${ }^{3,4^{*}}$ \\ ${ }^{1}$ Paul F. Glenn Center for Biology of Aging Research, Buck Institute for Research on Aging, \\ ${ }^{2}$ Princess Margaret Cancer Centre, University Health Network, ${ }^{3}$ Department of Experimental and Health Sciences, \\ Pompeu Fabra University (UPF), CIBER on Neurodegenerative diseases (CIBERNED), ICREA, Barcelona, Spain \\ and ${ }^{4}$ Spanish National Center on Cardiovascular Research (CNIC), Madrid, Spain
}

\begin{abstract}
Stem cells must preserve their function in order to sustain organ and tissue formation, homeostasis and repair. Adult stem cells, particularly those resident in tissues with little turnover, remain quiescent for most of their life, activating only in response to regenerative demands. Among the best studied long-lived quiescent stem cells are skeletal muscle stem cells, which are fully equipped to sustain repair in response to tissue trauma. Recent evidence indicates that the preservation of muscle stem-cell quiescence and regenerative capacity depends on intracellular networks linking metabolism and protein homeostasis. Here, we review recent research into how these networks control stem cell function and how their dysregulation contributes to aging, with a particular focus on senescence entry in extreme old age. We also discuss the implications of these new findings for anti-aging research in muscle stem-cell-based regenerative medicine.
\end{abstract}

KEY WORDS: stem cell, proteostasis, metabolism, aging, regeneration

\section{Introduction}

Aging is a major risk factor for human disease. The underlying causes of aging are now beginning to be understood, and researchers are beginning to construct an integrated view of the basic mechanisms underlying the aging process. Across species, aging compromises the structure and function of all adult tissues. The age-related decline in tissue function has been linked to the deregulation of several biological processes, referred to as hallmarks of aging (Kennedy et al., 2014, Lopez-Otin et al., 2013). Proper function of these processes is necessary to maintain tissue homeostasis throughout life. In metazoans, one of the mechanisms ensuring organismal homeostasis is tissue regeneration, sustained by tissue resident adult stem cells (Goodell and Rando, 2015).

Stem cell function is central to tissue regeneration and is regarded as an important point of convergence for processes related to organismal aging (Sharpless and DePinho, 2007). Stem cells are activated to promote cell replacement during normal tissue turnover and, critically, to avert tissue loss after injury and in disease. Although stem cell function is conserved across tissues and species, stem cell activity depends on the turnover of the host tissue (Bell and Van Zant, 2004, Jones and Rando, 2011). In resting conditions, most stem cell types are found in a quiescent state, activating and expanding only in response to stress or injury in order to repair the damaged tissue. As animals age, defective stem cell function is detected in multiple organs. Although the functional consequences vary greatly depending on the host tissue, the molecular mechanisms underlying age-related decline in regenerative capacity are well conserved across species and tissues, suggesting the existence of common targets for intervention to improve regenerative capacity in the elderly (Neves et al., 2017).

\section{Aging of quiescent muscle stem cells}

Skeletal muscle is a paradigm of tissue regeneration in a system harboring quiescent stem cells and with little remodeling and turnover. Tissue resident stem cells in skeletal muscle were first identified in the 1960s by electron microscopy (Mauro, 1961) and were named satellite cells due to their peripheral location beneath the myofiber basal lamina. Moreover, their chromatin structure and organelle composition suggested a mitotically and metabolically

\footnotetext{
Abbreviations used in this paper: ER, endoplasmic reticulum; NAD, nicotinamide adenine dinucleotide; ROS, reactive oxygen species; SASP, senescence associated secretory phenotype; UPR, unfolded protein response.
}

\footnotetext{
*Address correspondence to: Pura Muñoz-Cánoves. c/Dr. Aiguader, 88, E-08003 Barcelona, Spain; and c/Melchor Fernández-Almagro, 3, E-28029 Madrid, Spain. E-mail: pura.munoz@upf.edu; pura.munoz@cnic.es - (iD) https://orcid.org/0000-0002-7533-9047
} 
quiescent state of G0 cell-cycle reversible arrest. This muscle stem cell population is established early in development and is characterized by the expression of the paired box transcription factor Pax7 (Gros et al., 2005, Kassar-Duchossoy et al., 2005, Relaix et al., 2006). During embryonic and postnatal development, satellite cells sustain muscle growth, contributing new myonuclei to developing myofibers. However, by post-natal week three, satellite cells become quiescent, a state that is maintained throughout life except in response to tissue injury and exercise (Snijders et al., 2009, Yin et al., 2013).

The satellite cell quiescent state is reversible, with satellite cells able to activate in response to specific stimuli; however, a subpopulation of activated satellite cells can transit back to the quiescent state, a capacity known as self-renewal that is essential for the maintenance of the stem cell pool (Dumont et al., 2015). Satellite cell activation involves cell cycle entry, proliferation, differentiation, and fusion to form myofibers, and is essential for the replacement of damaged muscle tissue. The maintenance of reversible quiescence in satellite cells and their activation are thus essential for efficient tissue homeostasis and regeneration. In response to repeated injuries throughout life, reconstitution of the damaged tissue is coordinated with the maintenance of a healthy stem cell population that can continue to ensure optimal tissue homeostasis.

Aging diminishes the regenerative capacity of skeletal muscle in multiple ways, compromising recovery after injury. This age-related decline in muscle regenerative capacity has been attributed to a combination of extrinsic and intrinsic factors. Recent studies have strengthened earlier findings suggesting that defective muscle regeneration is driven by intrinsic pathways that coordinate metabolism, protein homeostasis (proteostasis), and senescence, especially in extreme old age. These changes in sarcopenic muscles are associated with a decline in muscle stem cell numbers and function; this decline, moreover, is linked to failed maintenance of reversible quiescence associated with cellular senescence and also to defects in differentiation and increased apoptosis (Chakkalakal et al., 2012, Conboy et al., 2003, Day et al., 2010, Garcia-Prat et al., 2013, Roth et al., 2000, Shefer et al., 2010, Shefer et al., 2006, Sousa-Victor et al., 2015, Wagers and Conboy, 2005, Zammit et al., 2002). Understanding the mechanisms that avert stem cell exhaustion during aging is therefore critical to devising strategies to improve regenerative capacity with aging. Recent evidence suggests that stem cell metabolic demands are coordinated with mechanisms that ensure cell fitness by preventing the accumulation of damaged proteins and organelles. This coordination is critical to maintaining satellite cell quiescence. Moreover, age-related changes in these processes are emerging as important contributors to age-related defects in muscle stem cell function (Garcia-Prat et al., 2017). In this review, we focus on the importance of proteome homeostasis and metabolism dynamics in the preservation of stem cell fitness of quiescence, how dysregulation of these processes accounts for their age-associated regenerative decline, and how they can be manipulated to slow this decline.

\section{Regulation of protein and organelle homeostasis in muscle stem cells}

Maintenance of the quiescent state in stem cells requires basal surveillance mechanisms to preserve the quality of the proteome (proteostasis). As proteins are synthesized, chaperones facilitate their appropriate folding and localization; misfolded proteins accumulate in the cytoplasm and endoplasmic reticulum (ER), triggering the unfolded protein response (UPR) to promote cell survival (Hartl et al., 2011). Further survival-supporting mechanisms involve the degradation of surplus or damaged proteins and organelles (Gidalevitz et al., 2011, Powers et al., 2009, Vilchez et al., 2014a, Vilchez et al., 2014b). Transition of satellite cells from quiescence to an activated state demands changes in protein composition, eliminating proteins involved in quiescence maintenance and supplying new proteins for cell-cycle progression. The quiescent state involves tight control of protein synthesis. Consistent with this, inhibition of the protein Dek, which promotes proliferative expansion through a mechanism involving miR-489, is required for the maintenance of muscle stem cell quiescence (Cheung et al., 2012). Preservation of quiescence also requires phosphorylation of translation initiation factor elF2 $\alpha$ (P-elF2 $\alpha$ ), which selectively represses translation. In mice, quiescent satellite cells that do not phosphorylate elF2 $\alpha$ (carrying a mutant elF2a allele or deficient for the elF2a phosphorylating kinase Perk) enter the cell cycle, but show defective self-renewal, which is detrimental for preservation of the muscle stem cell pool (Zismanov et al., 2016). Inhibition of PERK in satellite cells also prevents myofiber regeneration in adult mice by affecting the survival and differentiation of activated satellite cells (Xiong et al., 2017). The quiescent state is also protected by confinement of Myf5 myogenic commitment factor transcripts in RNA granules (Crist et al., 2012). Perk and P-elF2a regulate the UPRER through the activation of C/EBP homology protein (Chop), transcription factor4 (Atf4), and the chaperone protein BiP, all of which are more abundant in quiescent satellite cells (Zismanov et al., 2016). Additional studies have shown that ER stress and the UPR ${ }^{\mathrm{ER}}$ play a role in myogenesis in vitro (Acosta-Alvear et al., 2007, Alter and Bengal, 2011, Nakanishi et al., 2007, Nakanishi et al., 2005). To ensure proper maintenance, quiescent muscle stem cells have lower translation rates and more active stress response mechanisms than their more committed progeny; however, these stress response mechanisms are also needed for the response to injury and to ensure adequate stem cell expansion and function, and thus muscle regeneration.

Prominent among other proteostatic mechanisms required for quiescence maintenance is autophagy. Three types of autophagy occur in mammals: macroautophagy, microautophagy, and chaperone-mediated autophagy. In macroautophagy, referred to from here on simply as autophagy, a small portion of the cytoplasm is engulfed by an isolated membrane or phagophore, leading to the formation of a double-membrane vesicle called the autophagosome. The autophagosome then fuses with the lysosome, giving rise to an autolysosome in which materials inside the autophagosome (proteins or organelles) are degraded by lysosomal hydrolases (Mizushima and Komatsu, 2011). Degraded products are then recycled and used to support cell function and homeostasis. Autophagy is thus both an essential response to nutrient deprivation and a cytoplasmic quality control mechanism. Despite its origin as a stress response, resting muscle stem cells have a baseline autophagy activity that is required for quiescence maintenance. In resting young satellite cells, genetic loss of Atg7, a protein crucial for autophagosome formation, results in damage to proteins and organelles. Consequently, damaged mitochondria accumulate and generate high levels of reactive oxygen species (ROS). Autophagyimpairment triggers entry into senescence (a state of G0 irreversible 
cell cycle-arrest) that blocks cell function. Neutralization of ROS in autophagy-impaired young satellite cells avoids senescence and improves stem cell functions (Garcia-Prat et al., 2016b). Moreover, autophagy appears to be necessary for satellite-cell activation and subsequent myoblast differentiation, likely due to the high bioenergetic demands of these processes (Fiacco et al., 2016, Fortini et al., 2016, Tang and Rando, 2014).

\section{Metabolic regulation of muscle stem cells}

Metabolism is the sum of two activities: anabolism and catabolism. Anabolism requires energy acquired from the hydrolysis of adenosine triphosphate (ATP) or nicotinamide adenine dinucleotide phosphate (NADPH) to generate nucleotides, lipids, proteins and other cell constituent molecules. Catabolism refers to the processes whereby molecules are degraded to generate energy to meet anabolic demands. Two metabolic processes are crucial to the regulation of cell function. In the cytoplasm, glycolysis converts glucose to pyruvate, generating 2 net ATP molecules per molecule of glucose. Oxidative metabolism is a more efficient pathway for ATP generation whereby cells in oxygen-rich environments use oxidative phosphorylation (OxPhos) in mitochondria to generate about 34 additional ATP molecules per glucose molecule by oxidizing pyruvate to acetyl coenzyme A (acetyl-CoA) in the tricarboxylic acid (TCA) cycle (Ryall et al., 2015a; Chandel et al., 2016). Mitochondria also generate ROS, participate in amino-acid, lipid and nucleotide metabolism, and modify the net turnover of metabolites including NAD/NADH, AMP/ATP, SAM/SAH, and acetyl-CoA. These metabolites are important regulators of stem cell function, particularly epigenetic regulation, a subject that has been extensively reviewed elsewhere (Ryall et al., 2015a).

Quiescent satellite cells have high mitochondrial activity, which may reflect their localization in aerobic niches near capillaries (Christov et al., 2007, Ryall, 2013). Muscle stem cells transit from mitochondrial fatty acid oxidation to glycolysis, a process known as metabolic reprogramming, during their transition to more activated myogenic states (Ryall et al., 2015a). The switch to glycolysis may permit a faster increase in energy supply to meet the higher activation/differentiation requirements (Ryall et al., 2015a). Satellite cell activation also induces autophagy, presumably to provide additional energy through increased catabolism (Tang and Rando, 2014). Consistently, autophagy inhibition delays satellite cell activation, which can be partially rescued by exogenous delivery of pyruvate as an energy source, suggesting that autophagic flux is needed to generate sufficient energy for satellite cell exit from quiescence (Tang and Rando, 2014). The same study reported that the NADdependent deacetylase SIRT1 regulates autophagy and found that lack of SIRT1 delays satellite cell activation (Tang and Rando, 2014); despite this, in another study the metabolic switch to glycolysis was shown to decrease SIRT1 activity, causing the premature differentiation of activated satellite cells (Ryall et al., 2015b). The differences in outcome between these two studies likely reflect the different timing and methods used to evaluate satellite cell activation, as well as the different genetic systems used for SIRT1 ablation.

The broad modulation of gene expression required for satellite cell activation involves changes in chromatin structure and organization, which are in part under metabolic control (Ryall et al., 2015a). The metabolic switch to glycolysis in activated satellite cells and the consequent lowering of $\mathrm{NAD}^{+}$levels are associated with depressed nuclear SIRT1 deacetylase-mediated acetylation of H4K16. Genetic ablation of the SIRT1 deacetylase domain in satellite cells results in increased $\mathrm{H} 4 \mathrm{~K} 16$ acetylation and premature differentiation, suggesting that SIRT1 might function as a metabolic sensor, linking bioenergetic changes to the epigenetic regulation of satellite cell fate decisions (Ryall et al., 2015b). This idea is supported by the improved satellite cell function found in animals under caloric restriction. In mice, this metabolic intervention results in increased SIRT1 expression and enhanced function in transplantation experiments (Cerletti et al., 2012). Satellite cell function is also improved by other interventions that increase $\mathrm{NAD}^{+}$levels, including direct treatment with the NAD+ precursor nicotinamide riboside (Zhang et al., 2016).

Muscle stem cell function is also regulated by nutrient-sensing pathways. Maintenance of the satellite cell quiescent state does not require FoxO3a; however, during muscle regeneration, this transcription factor is critical for satellite cell self-renewal through the regulation of Notch signaling (Gopinath et al., 2014). Furthermore, the master metabolic regulator AMPK controls satellite cell selfrenewal (Theret et al., 2017), whereas the metabolic sensor Lkb1 is required for the maintenance of satellite cell quiescence (Shan et al., 2014). Consistently, Lkb1-deficient satellite cells prematurely activate and differentiate due to loss of quiescence (Shan etal., 2014). Lkb1 exerts a dual action, limiting satellite cell proliferation through the canonical AMPK/mTOR pathway and facilitating differentiation through phosphorylation of GSK-3B, a key component of the Wnt signaling pathway (Shan et al., 2014).

The satellite cell quiescent state is composed of two distinct phases: a G0 and an "alert" phase called $\mathrm{G}_{\mathrm{A}}$ (which does not imply cell-cycle entry) (Rodgers et al., 2014). Satellite cells can actively and reversibly transit between these phases in response to distant, injury-induced, systemic signals. Hepatocyte growth factor activator (HGFA) was recently identified as one such injury-regulated systemic signals in mice, sufficient to induce the transition of muscle stem cells to the $G_{A}$ state (Rodgers et al., 2017). This state i) facilitates faster activation of satellite cells in response to muscle damage, ii) is characterized by larger cells and higher mitochondrial activity, and iii) is regulated by mTORC1 via a Met/HGF axis. Consistently, satellite cells from TSC1-deficient mice can transit to $G_{A}$, whereas satellite cells from Raptor-deficient and cMet-deficient mice cannot. As a major nutrient sensor, protein synthesis regulator, and autophagy inhibitor, the mTOR pathway may interconnect the metabolic and proteostatic status of the satellite cell to preserve the quiescence state and its transition to activation.

Similar to most stem cell populations, satellite cells appear to be heterogeneous (Chakkalakal et al., 2012, Kuang et al., 2007, Rocheteau et al., 2012). A satellite cell subset expressing high levels of Pax7 has a higher self-renewal capacity in transplantation experiments and is less primed for commitment, correlating with lower metabolic activity and mitochondrial activity, than the more myogenic subset of satellite cells with low levels of Pax7 (Rocheteau et al., 2012). However, another study proposed elevated satellite cell mitochondrial activity as the cause of increased cell engraftment efficiency (Cerletti et al., 2012). More research is therefore needed into the metabolic requirements and functions of quiescent satellite cell subpopulations.

Signaling pathways such as mTOR and FoxO regulate autophagy, mitophagy and metabolism, and may additionally control distinct quiescent stem cell states (G0 and alert states), thus supporting the existence of interconnections among nutrient sensing signaling cascades, proteostasis, and metabolism in adult quiescentstem cells. 
Age-associated autophagic and metabolic changes in muscle stem cells: consequences for senescence entry

Stem cell exhaustion, cell senescence, dysregulated nutrient sensing, mitochondria dysfunction, and loss of proteostasis are 5 of the 9 hallmarks of aging covered in this review, contributing to age-related loss of regenerative capacity (Lopez-Otin et al., 2013). Recent studies have established a hierarchical mechanistic relation between these age-related phenomena. The fundamental biological processes controlling satellite cell function are proteostasis, mitochondrial function, and nutrient sensing (Garcia-Prat et al., 2017). During aging, the coordinated dysregulation of these processes results in geroconversion, characterized by accelerated entry into senescence in response to proliferative pressure, ultimately leading to stem cell exhaustion (Garcia-Prat et al., 2016b, Sousa-Victor etal., 2014a). Stem cell exhaustion is a determining factor in age-related loss of regenerative capacity, contributing to the aging process by accelerating chronic tissue damage due to inefficient repair (Blau et al., 2015, Chandel et al., 2016, Garcia-Prat et al., 2016c, Garcia-Prat et al., 2013, Oh et al., 2014, Schultz and Sinclair, 2016, Schworer et al., 2016, Sousa-Victor et al., 2015). Indeed, age-related diseases such as cardiovascular and neurodegenerative diseases are associated with impairments to these same pathways (Lopez-Otin et al., 2013, Lopez-Otin et al., 2016). Impaired proteostatic activity is an important hallmark of age-related neurodegeneration, contributing to diseases, such as Alzheimer's, Parkinson's, and Huntington's disease, where neuronal cells become susceptible to protein and organelle aggregation with age (Guan et al., 2013).

Quiescent stem cells, like differentiated cells, are non-dividing and therefore cannot eliminate their toxic organelles and protein aggregates during cell division. This property renders quiescent cells particularly susceptible to proteostatic stress and requires highly efficient proteome quality control mechanisms (Cuervo and Macian, 2014, Garcia-Prat et al., 2016a). In young satellite cells, basal autophagy sustains reversible quiescence by promoting proteostasis (Garcia-Prat et al., 2016b), but over time there is an age-related decline in autophagic activity that contributes to elevated proteostatic stress due to defective lysosome clearance. An important consequence of this defect is the accumulation of damaged mitochondria due to inefficient mitophagy (elimination of mitochondria by autophagy), leading to elevated ROS levels. Interestingly, high ROS levels have been linked to the epigenetic derepression of the INK4Alocus and consequent induction of the senescence-associated

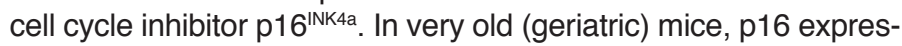
sion drives muscle stem cell senescence, leading to satellite cell exhaustion (Garcia-Prat et al., 2016b, Sousa-Victor et al., 2014a). A recent study suggests that the age-related decline in autophagy observed in muscle stem cells of mouse models is likely associated with the rewiring of rhythmic gene expression in old satellite cells, causing a disruption in the daily rhythmic oscillation of autophagy genes (Solanas et al., 2017).

Senescence is a state of permanent cell cycle arrest and high metabolic activity associated with a secretory phenotype (SASP, senescence associated secretory phenotype) that can further influence tissue health (Munoz-Espin and Serrano, 2014). Several studies report the accumulation of senescent cells in multiple tissues during aging and disease, and senescent cells are believed to further exacerbate tissue dysfunction (Collado et al., 2007, Jeyapalan et al., 2007, Jeyapalan and Sedivy, 2008, Lechel et al.,
2005, Satyanarayana et al., 2003, van Deursen, 2014). Although the mechanism linking senescent cell accumulation with organismal aging is not completely understood, some studies have established that the elimination of senescent cells is beneficial for organismal health, reducing tumor incidence, delaying age-related loss of tissue function, and extending lifespan (Baker et al., 2016, Chang et al., 2016). Senescent cells can induce paracrine senescence in their neighbors (Acosta et al., 2013), and this may be one of the mechanisms through which age-related dysfunction spreads. Moreover, the SASP may contribute to age-related diseases by driving pro-inflammatory signaling (Franceschi and Campisi, 2014). Thus, it is possible that strategies aimed at eliminating SASP can also improve healthspan. However, cellular senescence and the SASP are also important for organismal homeostasis in young organisms. Senescence is an important tumor suppressor mechanism, is induced during development to promote tissue remodeling and during wound healing to promote wound closure, and facilitates in vivo cell reprograming after tissue injury (Chiche et al., 2017, Collado et al., 2007, Demaria et al., 2014, Mosteiro et al., 2016, Munoz-Espin et al., 2013, Ocampo et al., 2016, Storer et al., 2013).

In skeletal muscle, satellite cell senescence has an important contribution for muscle aging (Sousa-Victor et al., 2014a). As in other tissues, senescence in satellite cells is associated with increased expression of $\mathrm{p} 16$ cell cycle-inhibitor, resulting from the polycomb protein-regulated epigenetic de-repression of the INK4a locus. Increased p16 expression leads to decreased phosphorylation of retinoblastoma $(\mathrm{Rb})$ protein and consequently to reduced expression of $\mathrm{Rb} / \mathrm{E} 2 \mathrm{~F}-$-regulated proliferation-related genes. These molecular alterations prevent stem cell activation, expansion, and self-renewal during muscle regeneration and force satellite cells under regenerative pressure into senescence, driving muscle stem cell exhaustion and compromising efficient muscle regeneration (Sousa-Victor etal., 2014a, Sousa-Victor et al., 2014b). These alterations in satellite cell biology are only observed in very old (geriatric) animals, suggesting that they result from life-long accumulation of alterations that culminate in cellular senescence. Because stem cells are essential for efficient regeneration, elimination of pre-senescent satellite cells in geriatric animals may improve regeneration. Rather, muscle regenerative capacity in aging animals is more likely to be improved by strategies aimed at preventing or reversing the senescence state. Indeed, genetic ablation or repression of $\mathrm{p} 16$ expression can restore regenerative capacity in geriatric mice (Sousa-Victor et al., 2014a). Moreover, muscle regenerative capacity was also restored by treatments that restore autophagy or counteract ROS, phenomena causally linked to the de-repression of the INK4a locus in geriatric satellite cells. A recent study in mice provided further evidence for the link between proteostatic pathway malfunction and age-associated stem cell senescence and regenerative failure, showing that deregulation of the mitochondrial unfolded protein response (UPR ${ }^{\mathrm{mt}}$ ) contributes to satellite cell senescence (Zhang et al., 2016). The authors reported that mitochondrial dysfunction, controlled by NAD+, is a hallmark of old satellite cells. Importantly, treatment with the $\mathrm{NAD}^{+}$precursor nicotinamide riboside (NR) can rejuvenate satellite cells by inducing the UPR ${ }^{\mathrm{mt}}$, improving mitochondrial function and preventing satellite cell senescence (Sousa-Victor et al., 2014a, Zhang et al., 2016).

The aging process, including stem cell aging, is also strongly related to changes in nutrient sensing pathways. In particular, increased $\mathrm{mTOR}$ signaling is associated with aging in several model organisms and is one of the most conserved targets for interventions in old 
age. Consistently, mTOR inhibition can extend lifespan and delay age-related diseases. Caloric restriction can have similar effects in older organisms, and the beneficial effect is thought to rely in part on the preservation of stem cell function (Signer and Morrison, 2013). Caloric restriction can preserve satellite cell function and enhance regenerative capacity in muscles from old animals, and these effects are accompanied by increases in mitochondrial content, oxygen consumption, and SIRT1 expression (Cerletti et al., 2012). Interestingly, there is a high degree of cooperation between metabolic and proteostatic mechanisms in maintaining the reversible quiescence of satellite cells. Inhibition of mTOR with rapamycin can improve satellite cell function in vivo, at least in part by increasing autophagy and thus promoting proteome stability (Garcia-Prat et al., 2016b). Another recent study suggested that proteostatic mechanisms also contribute to satellite cell senescence by affecting metabolic pathways (Baraibar et al., 2016). The authors reported that replicative senescence of human satellite cells is associated with accumulation of oxidized and damaged proteins, driven by decreased proteasome activity. Affected proteins include those involved in quality control and glycolytic enzymes, resulting in impaired glucose metabolism and a metabolic shift toward the use of branched chain amino acids or long chain fatty acids as energy substrates in senescent satellite cells (Baraibar et al., 2016).

Despite advances in anti-aging strategies, more studies are needed to decipher age-associated alterations perturbing muscle stem cell function in order to develop new treatments to improve health and longevity in humans.

\section{Conclusion}

Stem cells are among the most long-lived cells, and their functional decline is a major contributor to organismal aging and age-related diseases. Recent years have witnessed progress in our understanding of the aging process in stem cells from skeletal muscle, a paradigm of a low turnover tissue. These advances have identified shared hallmarks of aging stem cells, with alterations in protein
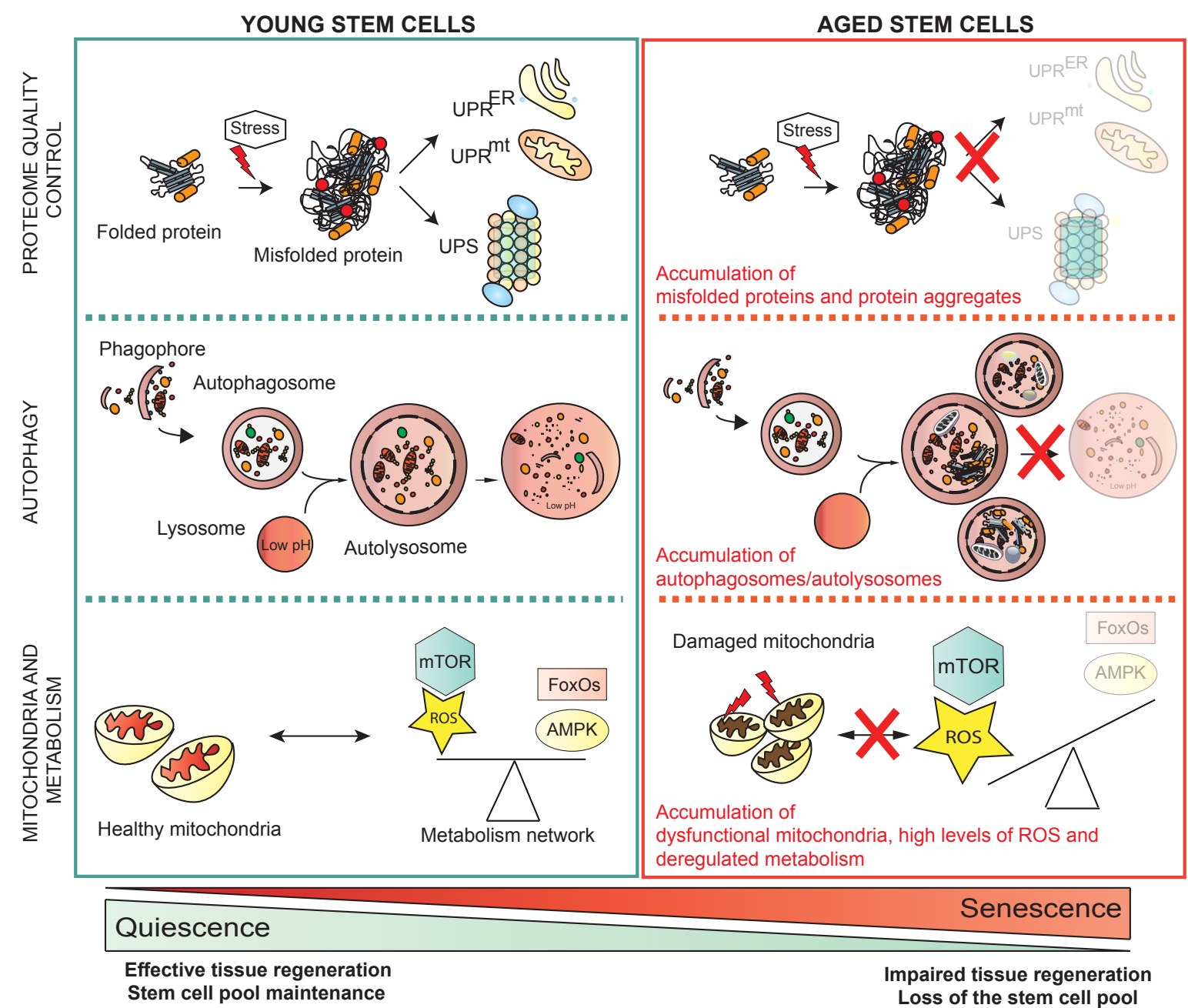

Fig. 1. Common alterations contributing to stem cell decline during aging and senescence entry. Long-lived quiescent satellite cells in young mice attenuate proteotoxicity and maintain organelle homeostasis through several mechanisms. These mechanisms include the ubiquitin proteasome system (UPS), the unfolded protein response in the endoplasmic reticulum (UPRER) and in mitochondria (UPR'), and autophagy (including mitophagy: the degradation of dysfunctional mitochondria by the autophagosome machinery). These mechanisms constitute a homeostatic "clean-up" process and are regulated by several signaling pathways associated with metabolism, such as the PI3K-mTOR, AMPK, and FoxO pathways. Alteration of one or more of these control processes is thought to contribute to stem cell quiescence decline, regenerative failure, and senescence entry in the geriatric life stage. 
quality control mechanisms and metabolic and sensing pathways emerging as major drivers of the blunting of regenerative capacity over time, particularly in the geriatric stage of life. At this life stage, dysregulation of these pathways has more dramatic consequences on satellite cells by provoking their entry into an irreversible senescence state (Fig. 1). Better understanding of these intrinsic networks will not only shed light on stem cell biology, but will also point the way toward novel treatments to prevent age-associated regenerative decline in skeletal muscle. As far as possible, research into agerelated diseases and regenerative medicine should focus on life style interventions, such as diet, aimed at modulating proteostasis and metabolism without major negative effects.

\section{Acknowledgements}

Work in the P.M.-C. lab is supported by MEIC (grant SAF2015-67369-R, a María de Maeztu Unit of Excellence award to UPF [MDM-2014-0370], and a Severo Ochoa Center of Excellence award to the CNIC [SEV-20150505]), the UPF-CNIC collaboration agreement, ERC-2016-ADG-741966, AFM, E-Rare/Eranet, MDA, Fundació MaratóTV3, and DPP-E. P.S.-V. is supported by the Glenn Foundation for Medical Research. Laura GarcíaPrat is supported by an EMBO Postdoctoral Fellowship (ALTF 420-2017). The authors apologize for omitting citations to some studies owing to space restrictions.

\section{References}

ACOSTA-ALVEAR, D., ZHOU, Y., BLAIS, A., TSIKITIS, M., LENTS, N.H., ARIAS, C., LENNON, C.J., KLUGER, Y. and DYNLACHT, B.D. (2007). XBP1 controls diverse cell type- and condition-specific transcriptional regulatory networks. $\mathrm{Mol}$ Cell 27: 53-66.

ACOSTA, J.C., BANITO, A., WUESTEFELD, T., GEORGILIS, A., JANICH, P., MORTON, J.P., ATHINEOS, D., KANG, T.W., LASITSCHKA, F., ANDRULIS, M. et al., (2013). A complex secretory program orchestrated by the inflammasome controls paracrine senescence. Nat Cell Biol 15: 978-990.

ALTER, J. and BENGAL, E. (2011). Stress-induced C/EBP homology protein (CHOP) represses MyoD transcription to delay myoblast differentiation. PLoS One6: e29498.

BAKER, D.J., CHILDS, B.G., DURIK, M., WIJERS, M.E., SIEBEN, C.J., ZHONG, J., SALTNESS, R.A., JEGANATHAN, K.B., VERZOSA, G.C., PEZESHKI, A. et al., (2016). Naturally occurring p16(Ink4a)-positive cells shorten healthy lifespan. Nature 530: 184-189.

BARAIBAR, M.A., HYZEWICZ, J., ROGOWSKA-WRZESINSKA, A., BULTEAU, A.L., PRIP-BUUS, C., BUTLER-BROWNE, G. and FRIGUET, B. (2016). Impaired energy metabolism of senescent muscle satellite cells is associated with oxidative modifications of glycolytic enzymes. Aging (Albany NY) 8: 3375-3389.

BELL, D.R. and VAN ZANT, G. (2004). Stem cells, aging, and cancer: inevitabilities and outcomes. Oncogene 23: 7290-7296.

BLAU, H.M., COSGROVE, B.D. and HO, A.T. (2015). The central role of muscle stem cells in regenerative failure with aging. Nat Med 21: 854-862.

CERLETTI, M., JANG, Y.C., FINLEY, L.W., HAIGIS, M.C. and WAGERS, A.J. (2012). Short-term calorie restriction enhances skeletal muscle stem cell function. Cell Stem Cell 10: 515-519.

CHAKKALAKAL, J.V., JONES, K.M., BASSON, M.A. and BRACK, A.S. (2012). The aged niche disrupts muscle stem cell quiescence. Nature 490: 355-360.

CHANDEL, N.S., JASPER, H., HO, T.T. and PASSEGUE, E. (2016). Metabolic regulation of stem cell function in tissue homeostasis and organismal ageing. Nat Cell Biol 18: 823-832.

CHANG, J., WANG, Y., SHAO, L., LABERGE, R.M., DEMARIA, M., CAMPISI, J., JANAKIRAMAN, K., SHARPLESS, N.E., DING, S., FENG, W. et al., (2016). Clearance of senescent cells by ABT263 rejuvenates aged hematopoietic stem cells in mice. Nat Med 22: 78-83.

CHEUNG, T.H., QUACH, N.L., CHARVILLE, G.W., LIU, L., PARK, L., EDALATI, A., YOO, B., HOANG, P. and RANDO, T.A. (2012). Maintenance of muscle stem-cell quiescence by microRNA-489. Nature 482: 524-528.

CHICHE, A., LE ROUX, I., VON JOEST, M., SAKAI, H., AGUIN, S.B., CAZIN, C.,
SALAM, R., FIETTE, L., ALEGRIA, O., FLAMANT, P. et al., (2017). Injury-Induced Senescence Enables In vivo Reprogramming in Skeletal Muscle. Cell Stem Cell 20: 407-414 e4.

CHRISTOV, C., CHRETIEN, F., ABOU-KHALIL, R., BASSEZ, G., VALLET, G., AUTHIER, F.J., BASSAGLIA, Y., SHININ, V., TAJBAKHSH, S., CHAZAUD, B. et al., (2007). Muscle satellite cells and endothelial cells: close neighbors and privileged partners. Mol Biol Cell 18: 1397-1409.

COLLADO, M., BLASCO, M.A. and SERRANO, M. (2007). Cellular senescence in cancer and aging. Cell 130: 223-233.

CONBOY, I.M., CONBOY, M.J., SMYTHE, G.M. and RANDO, T.A. (2003). Notchmediated restoration of regenerative potential to aged muscle. Science 302: 1575-1577.

CRIST, C.G., MONTARRAS, D. and BUCKINGHAM, M. (2012). Muscle satellite cells are primed for myogenesis but maintain quiescence with sequestration of Myf5 mRNA targeted by microRNA-31 in mRNP granules. Cell Stem Cell 11: 118-126.

CUERVO, A.M. and MACIAN, F. (2014). Autophagy and the immune function in aging Curr Opin Immunol 29: 97-104

DAY, K., SHEFER, G., SHEARER, A. and YABLONKA-REUVENI, Z. (2010). The depletion of skeletal muscle satellite cells with age is concomitant with reduced capacity of single progenitors to produce reserve progeny. Dev Bio/340:330-343.

DEMARIA, M., OHTANI, N., YOUSSEF, S.A., RODIER, F., TOUSSAINT, W., MITCHELL, J.R., LABERGE, R.M., VIJG, J., VAN STEEG, H., DOLLE, M.E. et al., (2014). An essential role for senescent cells in optimal wound healing through secretion of PDGF-AA. Dev Cell 31: 722-733.

DUMONT, N.A., WANG, Y.X. and RUDNICKI, M.A. (2015). Intrinsic and extrinsic mechanisms regulating satellite cell function. Development 142: 1572-1581.

FIACCO, E., CASTAGNETTI, F., BIANCONI, V., MADARO, L., DE BARDI, M., NAZIO, F., D'AMICO, A., BERTINI, E., CECCONI, F., PURI, P.L. et al., (2016). Autophagy regulates satellite cell ability to regenerate normal and dystrophic muscles. Cell Death Differ 23: 1839-1849.

FORTINI, P., FERRETTI, C., IORIO, E., CAGNIN, M., GARRIBBA, L., PIETRAFORTE, D., FALCHI, M., PASCUCCI, B., BACCARINI, S., MORANI, F. et al., (2016). The fine tuning of metabolism, autophagy and differentiation during in vitromyogenesis. Cell Death Dis 7: e2168.

FRANCESCHI, C. and CAMPISI, J. (2014). Chronic inflammation (inflammaging) and its potential contribution to age-associated diseases. J Gerontol A Biol SCl Med Sci 69 Suppl 1: S4-9.

GARCIA-PRAT, L., MARTINEZ-VICENTE, M. and MUNOZ-CANOVES, P. (2016a). Autophagy: a decisive process for stemness. Oncotarget 7: 12286-12288.

GARCIA-PRAT, L., MARTINEZ-VICENTE, M., PERDIGUERO, E., ORTET, L., RODRIGUEZ-UBREVA, J., REBOLLO, E., RUIZ-BONILLA, V., GUTARRA, S., BALLESTAR, E., SERRANO, A.L. et al., (2016b). Autophagy maintains stemness by preventing senescence. Nature 529: 37-42.

GARCIA-PRAT, L., MUNOZ-CANOVES, P. and MARTINEZ-VICENTE, M. (2016c) Dysfunctional autophagy is a driver of muscle stem cell functional decline with aging. Autophagy 12: 612-613.

GARCIA-PRAT, L., SOUSA-VICTOR, P. and MUNOZ-CANOVES, P. (2013). Functional dysregulation of stem cells during aging: a focus on skeletal muscle stem cells. FEBS J 280: 4051-4062.

GARCIA-PRAT, L., SOUSA-VICTOR, P. and MUNOZ-CANOVES, P. (2017). Proteostatic and Metabolic Control of Stemness. Cell Stem Cell 20: 593-608.

GIDALEVITZ, T., PRAHLAD, V. and MORIMOTO, R.I. (2011). The stress of protein misfolding: from single cells to multicellular organisms. Cold Spring Harb Perspect Biol 3(6). pii: a009704. doi: 10.1101/cshperspect.a009704.

GOODELL, M.A. and RANDO, T.A. (2015). Stem cells and healthy aging. Science 350: 1199-204

GOPINATH, S.D., WEBB, A.E., BRUNET, A. and RANDO, T.A. (2014). FOXO3 promotes quiescence in adult muscle stem cells during the process of self-renewal. Stem Cell Reports 2: 414-426.

GROS, J., MANCEAU, M., THOME, V. and MARCELLE, C. (2005). A common somitic origin for embryonic muscle progenitors and satellite cells. Nature 435: 954-958.

GUAN, J.L., SIMON, A.K., PRESCOTT, M., MENENDEZ, J.A., LIU, F., WANG, F., WANG, C., WOLVETANG, E., VAZQUEZ-MARTIN, A. and ZHANG, J. (2013). Autophagy in stem cells. Autophagy 9: 830-849.

HARTL, F.U., BRACHER, A. and HAYER-HARTL, M. (2011). Molecular chaperones in protein folding and proteostasis. Nature 475: 324-332. 
JEYAPALAN, J.C., FERREIRA, M., SEDIVY, J.M. and HERBIG, U. (2007). Accumulation of senescent cells in mitotic tissue of aging primates. Mech Ageing Dev 128: 36-44.

JEYAPALAN, J.C. and SEDIVY, J.M. (2008). Cellular senescence and organismal aging. Mech Ageing Dev 129: 467-474.

JONES, D.L. and RANDO, T.A. (2011). Emerging models and paradigms for stem cell ageing. Nat Cell Biol 13: 506-512.

KASSAR-DUCHOSSOY, L., GIACONE, E., GAYRAUD-MOREL, B., JORY,A., GOMES, D. and TAJBAKHSH, S. (2005). Pax3/Pax7 mark a novel population of primitive myogenic cells during development. Genes Dev 19: 1426-1431.

KENNEDY, B.K., BERGER, S.L., BRUNET, A., CAMPISI, J., CUERVO, A.M., EPEL, E.S., FRANCESCHI, C., LITHGOW, G.J., MORIMOTO, R.I., PESSIN, J.E. et al., (2014). Geroscience: linking aging to chronic disease. Cell 159: 709-713.

KUANG, S., KURODA, K., LE GRAND, F. and RUDNICKI, M.A. (2007). Asymmetric self-renewal and commitment of satellite stem cells in muscle. Cell 129: 999-1010.

LECHEL, A., SATYANARAYANA, A., JU, Z., PLENTZ, R.R., SCHAETZLEIN, S., RUDOLPH, C., WILKENS, L., WIEMANN, S.U., SARETZKI, G., MALEK, N.P. et al., (2005). The cellular level of telomere dysfunction determines induction of senescence or apoptosis in vivo. EMBO Rep 6: 275-281.

LOPEZ-OTIN, C., BLASCO, M.A., PARTRIDGE, L., SERRANO, M. and KROEMER, G. (2013). The hallmarks of aging. Cell 153: 1194-1217.

LOPEZ-OTIN, C., GALLUZZI, L., FREIJE, J.M., MADEO, F. and KROEMER, G. (2016). Metabolic Control of Longevity. Cell 166: 802-821.

MAURO, A. (1961). Satellite cells of skeletal fibers. J. Biophys. Biochem. Cytol. 9: 493-495.

MIZUSHIMA, N. and KOMATSU, M. (2011). Autophagy: renovation of cells and tissues. Cell 147: 728-741.

MOSTEIRO, L., PANTOJA, C., ALCAZAR, N., MARION, R.M., CHONDRONASIOU, D., ROVIRA, M., FERNANDEZ-MARCOS, P.J., MUNOZ-MARTIN, M., BLANCOAPARICIO, C., PASTOR, J. etal., (2016). Tissue damage and senescence provide critical signals for cellular reprogramming in vivo. Science 354(6315). pii: aaf4445.

MUNOZ-ESPIN, D., CANAMERO, M., MARAVER, A., GOMEZ-LOPEZ, G., CONTRERAS, J., MURILLO-CUESTA, S., RODRIGUEZ-BAEZA, A., VARELA-NIETO, I., RUBERTE, J., COLLADO, M. et al., (2013). Programmed cell senescence during mammalian embryonic development. Cell 155: 1104-1118.

MUNOZ-ESPIN, D. and SERRANO, M. (2014). Cellular senescence: from physiology to pathology. Nat Rev Mol Cell Biol 15: 482-496.

NAKANISHI, K., DOHMAE, N. and MORISHIMA, N. (2007). Endoplasmic reticulum stress increases myofiber formation in vitro. FASEB J 21: 2994-3003.

NAKANISHI, K., SUDO, T. and MORISHIMA, N. (2005). Endoplasmic reticulum stress signaling transmitted by ATF6 mediates apoptosis during muscle development. J Cell Biol 169: 555-560.

NEVES, J., SOUSA-VICTOR, P. and JASPER, H. (2017). Rejuvenating Strategies for Stem Cell-Based Therapies in Aging. Cell Stem Cell 20: 161-175.

OCAMPO, A., REDDY, P., MARTINEZ-REDONDO, P., PLATERO-LUENGo, A., HATANAKA, F., HISHIDA, T., LI, M., LAM, D., KURITA, M., BEYRET, E. et al., (2016). In vivo Amelioration of Age-Associated Hallmarks by Partial Reprogramming. Cell 167: 1719-1733 e12.

OH, J., LEE, Y.D. and WAGERS, A.J. (2014). Stem cell aging: mechanisms, regulators and therapeutic opportunities. Nat Med 20: 870-880.

POWERS, E.T., MORIMOTO, R.I., DILLIN, A., KELLY, J.W. and BALCH, W.E. (2009). Biological and chemical approaches to diseases of proteostasis deficiency. Annu Rev Biochem 78: 959-991.

RELAIX, F., MONTARRAS, D., ZAFFRAN, S., GAYRAUD-MOREL, B., ROCANCOURT, D., TAJBAKHSH, S., MANSOURI, A., CUMANO, A. and BUCKINGHAM, M. (2006). Pax3 and Pax7 have distinct and overlapping functions in adult muscle progenitor cells. J Cell Biol 172: 91-102.

ROCHETEAU, P., GAYRAUD-MOREL, B., SIEGL-CACHEDENIER, I., BLASCO, M.A. and TAJBAKHSH, S. (2012). A subpopulation of adult skeletal muscle stem cells retains all template DNA strands after cell division. Cell 148: 112-125.

RODGERS, J.T., KING, K.Y., BRETT, J.O., CROMIE, M.J., CHARVILLE, G.W., MAGUIRE, K.K., BRUNSON, C., MASTEY, N., LIU, L., TSAI, C.R. et al., (2014). mTORC1 controls the adaptive transition of quiescent stem cells from G0 to G(Alert). Nature 510: 393-396.

RODGERS, J.T., SCHROEDER, M.D., MA, C. and RANDO, T.A. (2017). HGFA Is an Injury-Regulated Systemic Factor that Induces the Transition of Stem Cells into
GAlert. Cell Rep 19: 479-486.

ROTH, S.M., MARTEL, G.F., IVEY, F.M., LEMMER, J.T., METTER, E.J., HURLEY, B.F. and ROGERS, M.A. (2000). Skeletal muscle satellite cell populations in healthy young and older men and women. Anat Rec 260: 351-358.

RYALL, J.G. (2013). Metabolic reprogramming as a novel regulator of skeletal muscle development and regeneration. FEBS J 280: 4004-4013.

RYALL, J.G., CLIFF, T., DALTON, S. and SARTORELLI, V. (2015a). Metabolic Reprogramming of Stem Cell Epigenetics. Cell Stem Cell 17: 651-662.

RYALL, J.G., DELL'ORSO, S., DERFOUL, A., JUAN, A., ZARE, H., FENG, X., CLERMONT, D., KOULNIS, M., GUTIERREZ-CRUZ, G., FULCO, M. et al., (2015b). The NAD(+)-dependent SIRT1 deacetylase translates a metabolic switch into regulatory epigenetics in skeletal muscle stem cells. Cell Stem Cell 16: 171-183.

SATYANARAYANA, A., WIEMANN, S.U., BUER, J., LAUBER, J., DITTMAR, K.E., WUSTEFELD, T., BLASCO, M.A., MANNS, M.P. and RUDOLPH, K.L. (2003). Telomere shortening impairs organ regeneration by inhibiting cell cycle re-entry of a subpopulation of cells. EMBO J 22: 4003-4013.

SCHULTZ, M.B. and SINCLAIR, D.A. (2016). When stem cells grow old: phenotypes and mechanisms of stem cell aging. Development 143: 3-14.

SCHWORER, S., BECKER, F., FELLER, C., BAIG, A.H., KOBER, U., HENZE, H., KRAUS, J.M., XIN, B., LECHEL, A., LIPKA, D.B. et al., (2016). Epigenetic stress responses induce muscle stem-cell ageing by Hoxa9 developmental signals. Nature 540: 428-432.

SHAN, T., ZHANG, P., LIANG, X., BI, P., YUE, F. and KUANG, S. (2014). Lkb1 is indispensable for skeletal muscle development, regeneration, and satellite cell homeostasis. Stem Cells 32: 2893-2907.

SHARPLESS, N.E. and DEPINHO, R.A. (2007). How stem cells age and why this makes us grow old. Nat Rev Mol Cell Biol 8: 703-713.

SHEFER, G., RAUNER, G., YABLONKA-REUVENI, Z. and BENAYAHU, D. (2010). Reduced satellite cell numbers and myogenic capacity in aging can be alleviated by endurance exercise. PLoS One 5: e13307.

SHEFER, G., VAN DE MARK, D.P., RICHARDSON, J.B. and YABLONKA-REUVENI, Z. (2006). Satellite-cell pool size does matter: defining the myogenic potency of aging skeletal muscle. Dev Biol 294: 50-66.

SIGNER, R.A. and MORRISON, S.J. (2013). Mechanisms that regulate stem cell aging and life span. Cell Stem Cell 12: 152-165.

SNIJDERS, T., VERDIJK, L.B. and VAN LOON, L.J. (2009). The impact of sarcopenia and exercise training on skeletal muscle satellite cells. Ageing Res Rev8:328-338.

SOLANAS, G., PEIXOTO, F.O., PERDIGUERO, E., JARDI, M., RUIZ-BONILLA, V., DATTA, D., SYMEONIDI, A., CASTELLANOS, A., WELZ, P.S., CABALLERO, J.M. et al., (2017). Aged Stem Cells Reprogram Their Daily Rhythmic Functions to Adapt to Stress. Cell 170: 678-692 e20.

SOUSA-VICTOR, P., GARCIA-PRAT, L., SERRANO, A.L., PERDIGUERO, E. and MUNOZ-CANOVES, P. (2015). Muscle stem cell aging: regulation and rejuvenation. Trends Endocrinol Metab 26: 287-296.

SOUSA-VICTOR, P., GUTARRA, S., GARCIA-PRAT, L., RODRIGUEZ-UBREVA, J., ORTET, L., RUIZ-BONILLA, V., JARDI, M., BALLESTAR, E., GONZALEZ, S., SERRANO, A.L. et al., (2014a). Geriatric muscle stem cells switch reversible quiescence into senescence. Nature 506: 316-321.

SOUSA-VICTOR, P., PERDIGUERO, E. and MUNOZ-CANOVES, P. (2014b). Geroconversion of aged muscle stem cells under regenerative pressure. Cell Cycle 13: 3183-3190.

STORER, M., MAS, A., ROBERT-MORENO, A., PECORARO, M., ORTELLS, M.C., DI GIACOMO, V., YOSEF, R., PILPEL, N., KRIZHANOVSKY, V., SHARPE, J. et al., (2013). Senescence is a developmental mechanism that contributes to embryonic growth and patterning. Cell 155: 1119-1130.

TANG, A.H. and RANDO, T.A. (2014). Induction of autophagy supports the bioenergetic demands of quiescent muscle stem cell activation. EMBO J33: 2782-2797.

THERET, M., GSAIER, L., SCHAFFER, B., JUBAN, G., BEN LARBI, S., WEISSGAYET, M., BULTOT, L., COLLODET, C., FORETZ, M., DESPLANCHES, D. et al., (2017). AMPKalpha1-LDH pathway regulates muscle stem cell self-renewal by controlling metabolic homeostasis. EMBO J 36: 1946-1962.

VANDEURSEN, J.M. (2014). The role of senescent cells in ageing. Nature 509:439-446.

VILCHEZ, D., SAEZ, I. and DILLIN, A. (2014a). The role of protein clearance mechanisms in organismal ageing and age-related diseases. Nat Commun 5: 5659.

VILCHEZ, D., SIMIC, M.S. and DILLIN, A. (2014b). Proteostasis and aging of stem 
cells. Trends Cell Biol 24: 161-170.

WAGERS, A.J. and CONBOY, I.M. (2005). Cellular and molecular signatures of muscle regeneration: current concepts and controversies in adult myogenesis. Cell 122: 659-667.

XIONG, G., HINDI, S.M., MANN, A.K., GALLOT, Y.S., BOHNERT, K.R., CAVENER, D.R., WHITTEMORE, S.R. and KUMAR,A. (2017). The PERK arm of the unfolded protein response regulates satellite cell-mediated skeletal muscle regeneration. eLife 6 .

YIN, H., PRICE, F. and RUDNICKI, M.A. (2013). Satellite cells and the muscle stem cell niche. Physiol Rev 93: 23-67.

ZAMMIT, P.S., HESLOP, L., HUDON, V., ROSENBLATT, J.D., TAJBAKHSH, S.,
BUCKINGHAM, M.E., BEAUCHAMP, J.R. and PARTRIDGE, T.A. (2002). Kinetics of myoblast proliferation show that resident satellite cells are competent to fully regenerate skeletal muscle fibers. Exp Cell Res 281: 39-49.

ZHANG, H., RYU, D., WU, Y., GARIANI, K., WANG, X., LUAN, P., D'AMICO, D., ROPELLE, E.R., LUTOLF, M.P., AEBERSOLD, R. et al., (2016). NAD(+) repletion improves mitochondrial and stem cell function and enhances life span in mice. Science 352: 1436-1443.

ZISMANOV, V., CHICHKOV, V., COLANGELO, V., JAMET, S., WANG, S., SYME, A., KOROMILAS, A.E. and CRIST, C. (2016). Phosphorylation of elF2alpha Is a Translational Control Mechanism Regulating Muscle Stem Cell Quiescence and Self-Renewal. Cell Stem Cell 18: 79-90. 


\section{Further Related Reading, published previously in the Int. J. Dev. Biol.}

Distinct patterns of MMP-9 and MMP-2 activity in slow and fast twitch skeletal muscle regeneration in vivo

Malgorzata Zimowska, Edyta Brzoska, Marta Swierczynska, Wladyslawa Streminska and Jerzy Moraczewski

Int. J. Dev. Biol. (2008) 52: 307-314

https://doi.org/10.1387/ijdb.072331mz

Coexpression of Notch3 and Rgs5 in the pericyte-vascular smooth muscle cell axis in response to pulp injury Henrik Lovschall, Thimios A. Mitsiadis, Knud Poulsen, Kristina H. Jensen and Annette L. Kjeldsen Int. J. Dev. Biol. (2007) 51: 715-721

https://doi.org/10.1387/ijdb.072393hl

Key apoptosis regulating proteins are down-regulated during postnatal tissue development

Shane D. Madden, Maryanne Donovan and Thomas G. Cotter

Int. J. Dev. Biol. (2007) 51: 415-424

https://doi.org/10.1387/ijdb.062263sm

The homeobox gene Msx in development and transdifferentiation of jellyfish striated muscle

Sabina Galle, Nathalie Yanze and Katja Seipel

Int. J. Dev. Biol. (2005) 49: 961-967

http://www.intjdevbiol.com/web/paper/052009sg

Distinctive expression of Myf5 in relation to differentiation and plasticity of newt muscle cells

Yutaka Imokawa, Phillip B. Gates, Young-Tae Chang, Hans-Georg Simon and Jeremy P. Brockes Int. J. Dev. Biol. (2004) 48: 285-291

http://www.intjdevbiol.com/web/paper/031787yi

Limb muscle development

Bodo Christ and Beate Brand-Saberi

Int. J. Dev. Biol. (2002) 46: 905-914

http://www.intjdevbiol.com/web/paper/12455628

Constant and continuous growth reduction as a possible cause of ageing

Etienne Geraert

Int. J. Dev. Biol. (2004) 48: 271-274

http://www.intjdevbiol.com/web/paper/031773eg

5 yr ISI Impact Factor $(2016)=2.421$
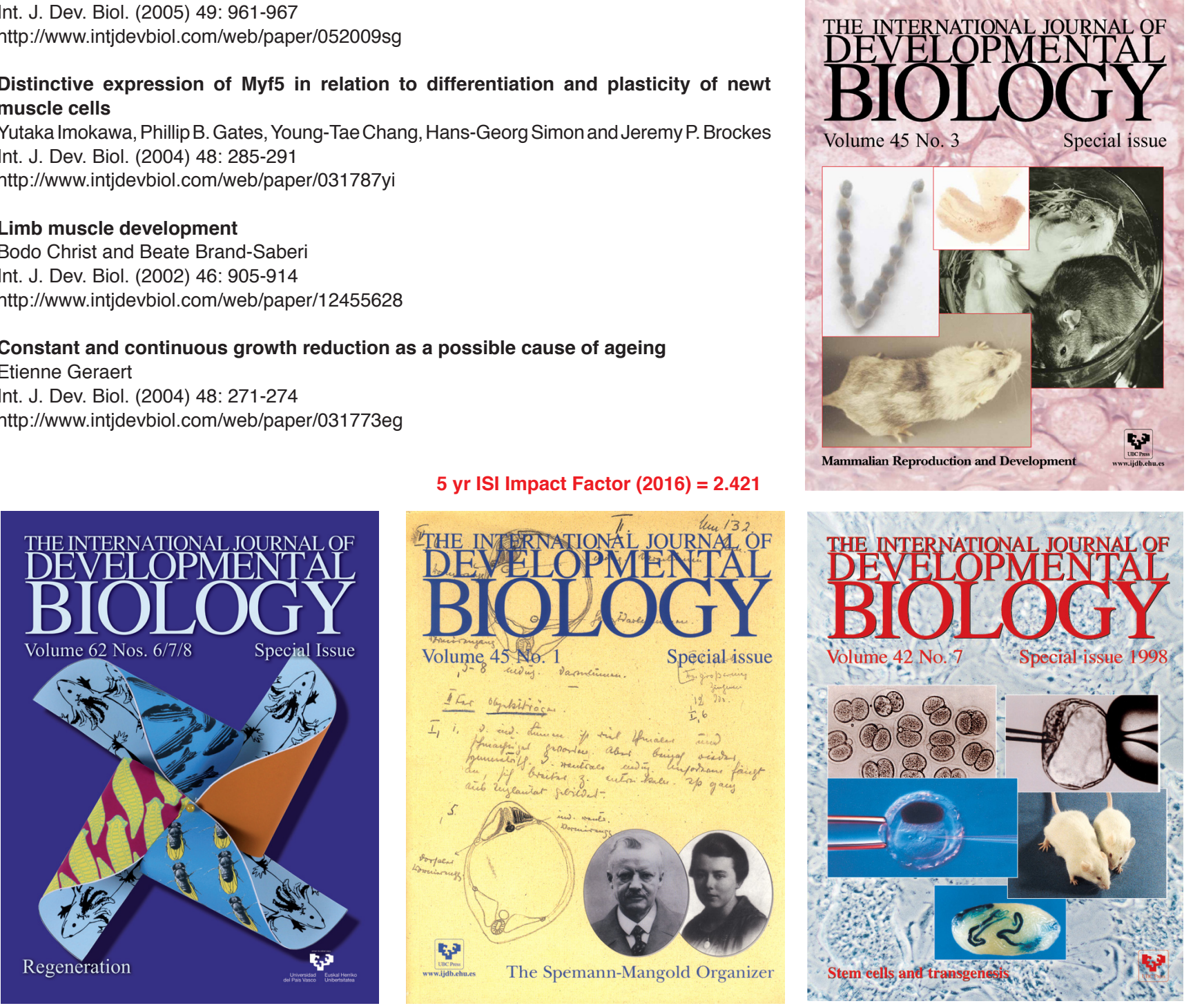